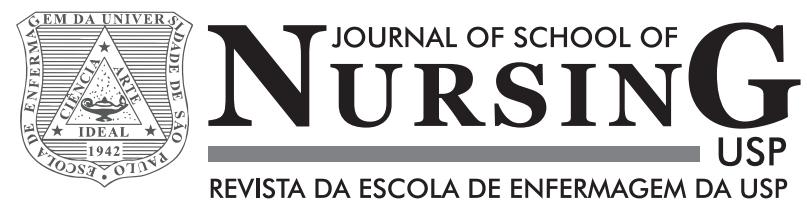

\title{
Trauma in the elderly caused by traffic accident: integrative review*
}

\author{
Trauma no idoso por acidente de trânsito: revisão integrativa \\ Trauma en el anciano por accidente de tránsito: revisión integradora
}

Ana Maria Ribeiro dos Santos ${ }^{1}$, Rosalina Aparecida Partezani Rodrigues ${ }^{2}$, Marina Aleixo Diniz ${ }^{3}$

\footnotetext{
* Extracted from the thesis "Trauma por acidente de trânsito no idoso: fatores de risco e consequências", Nursing School of Ribeirão Preto, University of São Paulo, 2013.

${ }^{1} \mathrm{PhD}$, Nursing department, Health Sciences Center, Federal University of Piauí, Teresina, PI, Brazil.

${ }^{2}$ Full Professor, School of Nursing of Ribeirão Preto, University of Sao Paulo, Ribeirão Preto, SP, Brazil.

${ }^{3} \mathrm{PhD}$ Student, Graduate Program in Fundamental Nursing, School of Nursing of Ribeirão Preto, University of Sao Paulo, Ribeirao Preto, SP, Brazil.
}

\section{ABSTRACT}

Objective: To describe the scientific knowledge produced about trauma in the elderly caused by traffic accidents in healthcare area studies. Methods: Integrative review of studies from 2003 to 2013 searched in LILACS, SciELO, PubMed and CINHAL databases. We used combination of the descriptors injuries, wounds and accidents, in English, Portuguese and Spanish languages. Results: 32 studies were selected. In the thematic analysis, three categories emerged: epidemiological data from traffic accidents involving elderly; traffic accidents with elderly pedestrians; and trauma care in the elderly. We observed increased incidence of trauma in most countries and pedestrians represented a large part of the victims. Among these, the elderly are the most vulnerable group. Conclusion: Studies showed that trauma care in the elderly need protocols and professionals with training in gerontology specialized in trauma care services.

\section{DESCRIPTORS}

Aged; Wounds and Injuries; Accidents, Traffic; Nursing; Review.
Correspondence Addressed to: Ana Maria Ribeiro dos Santos Rua Professor Madeira, 1519 - Horto Florestal CEP 64052-480 - Teresina, PI, Brasil E-mail: ana.mrsantos@gmail.com 


\section{INTRODUCTION}

Population aging is a worldwide phenomenon that, although initially occurred in Western European countries, that made their early demographic transition, is currently a reality also in countries of Latin America and the $\mathrm{Ca}-$ ribbean, which have initiated this process of demographic transition for about 50 years ${ }^{(1)}$.

Parallel to this phenomenon, trauma in the elderly have proved to be a major public health problem, with a tendency to progressive worsening ${ }^{(2)}$. In 2002 , more than 193,000 deaths caused by traffic were registered in the world among people who were 60 years or more. In developing countries, the mortality rate for this cause for 100,000 inhabitants, in this population, was the highest compared to other age groups. United Nations projections indicate that the elderly constitute a growing percentage of the population over the next 30 years and the vulnerability to be killed or seriously injured in traffic is an increasingly important issue in the world ${ }^{(3)}$.

In Brazil, in 2007, the Mortality information system of the Ministry of health recorded 18,946 deaths of people older than 60 years by external causes, of which 5,084 were the result of some kind of transport accident ${ }^{(4)}$.

Therefore, it is believed that the knowledge about traffic accident trauma in the elderly is essential for the formulation of effective policies and programs for its prevention, enabling the reduction of the indexes in this age group and, consequently, promoting a better quality of life.

Considering the complexity of the aging process, combined with the seriousness that the traffic accidents represent for the elderly population, it was deemed important to investigate the current situation of the event in this population, in order to contribute with the actions of public management and of health professionals entered in the various health care programs in relation to responsibilities and possibilities for prevention and control of these occurrences. In this sense, the present study aimed to describe the scientific knowledge produced about trauma in the elderly caused by traffic accidents in healthcare publications.

\section{METHODS}

It was used as a method the integrative review of literature search, which allows the inclusion of theoretical and empirical literature in the study, as well as studies with different methodological approaches ${ }^{(5)}$.

In the preparation of this review, the following steps were used: selection of the study question, establishing the criteria for the selection of the sample and literature search, definition of the information to be extracted from selected studies, assessment of studies included in the review, interpretation of results and presentation of the review ${ }^{(5)}$.

Initially, the issue that has guided the study consisted of: what are the scientific knowledge produced about trauma in the elderly caused by traffic accidents, in healthcare publications?

For the selection of the publications to be included in the review, the following criteria for inclusion were adopt- ed: primary studies, published in the period from January 2003 to August 2013, in Portuguese, English and Spanish languages, conducted with people who were 60 years old or more. Chapters of books, theses, doctoral dissertations, technical reports and studies related to other types of accidents, as well as other age groups were excluded.

Search was held in the databases Literature Latin American and Caribbean Health Sciences (LILACS), Scientific Electronic Library Online (SciELO), Medical Literature Analysis and Retrieval System Online (PubMed) and Cumulative Index to Nursing and Allied Health Literature (CINAHL), using the controlled descriptors: wounds and injuries; and accidents.

The search was conducted in August of 2013, with 616 studies in PubMed database, 366 in LILACS, 79 in CINAHL and 45 in SciELO, totaling 1,106 publications. After that, we selected the studies, considering, at first, as potentially eligible, studies whose titles and summaries reported as subject people with 60 years or more; in this step 58 publications were elected and then we proceeded to the integral reading of the selected material. After this analysis, 12 studies were excluded, five for dealing with review of the literature and seven by approaching specific lesions resulting from other types of accidents, not related to traffic accident, remaining only 46 studies. Of this total, 14 publications were repeated in the databases, and were considered only once, at the end of this process, there were 32 studies selected, being 12 in the PubMed database, 10 in LILACS, five in CINAHL and five in SciELO, which were included in the sample of this review. The selection process was developed by two publications revisers independently and is represented in Figure 1.

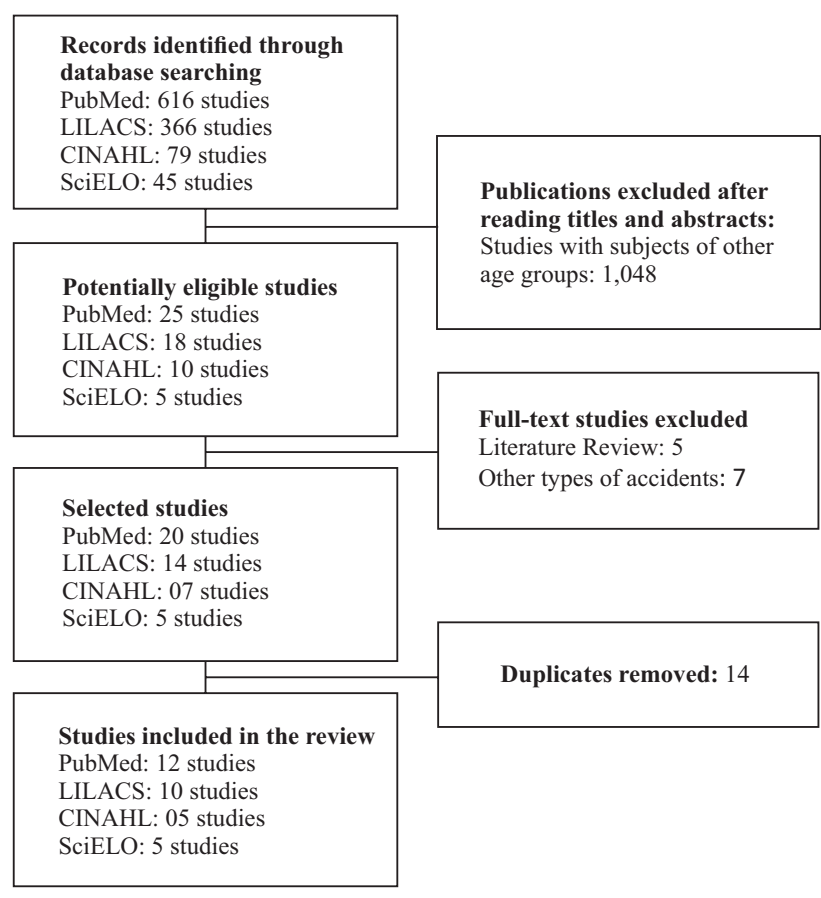

Figure 1 - Search strategy for selection of articles included in the review - Teresina, PI, 2013. 
For the data extraction, a data collection form designed for this purpose by the authors of the study was used, containing information about authors and year of publication of the study; database and journals; place of performance and language of publication; objectives, results and conclusions of the studies.

The final synthesis was developed in a descriptive form, with regard to the objectives, results and conclusions obtained from each of the studies. Such data were grouped by similarity and organized into thematic categories. Finally, the last step corresponded to the elaboration of the document with the complete description of the steps followed.

\section{RESULTS}

Table 1 presents a summary of studies included in the review, which formed the corpus of the study and represented the essence for the processing of the results, discussion and its conclusion on the subject of trauma from traffic accidents in the elderly.

It was found that most of the studies were published in 2010 , accounting for a total of seven (22\%). In the case of recurrent, we observed 19 different journals, especially the Journal Science \& Public Health, which published five articles and international journals Injury Prevention and Annual proceedings of the Association for the Advancement of Automotive Medicine, which have published three studies each one.

Box 1 - Summary of the included studies on trauma by traffic accidents in the elderly - Teresina, PI, 2013.

\begin{tabular}{|c|c|c|c|}
\hline $\begin{array}{l}\text { Year/ } \\
\text { country }\end{array}$ & $\begin{array}{l}\text { Authors } \\
\text { Design } \\
\text { Sample }\end{array}$ & Objectives & $\begin{array}{l}\text { Results } \\
\text { Conclusions }\end{array}$ \\
\hline $\begin{array}{l}2013 \\
\text { EUA } \\
\text { PubMed }\end{array}$ & $\begin{array}{l}\text { Mcelroy LM, Juern JJ, Bertleson } \\
\text { A, Xiang Q, Szabo A, } \\
\text { Weigelt }^{(6)} \text {. Cross-sectional } \\
(\mathrm{n}=945)\end{array}$ & $\begin{array}{l}\text { To investigate pedestrian road traffic } \\
\text { accidents and characterize the popu- } \\
\text { lation, the injury, the time of the ac- } \\
\text { cident comparing to previous studies. }\end{array}$ & $\begin{array}{l}\text { The elderly accounted for } 18.7 \% \text { of the population, } \\
39 \% \text { were } 80 \text { years or older. More admitted to ICU, } \\
\text { and the mortality rate doubled in the younger. }\end{array}$ \\
\hline $\begin{array}{l}2013 \\
\text { Brasil } \\
\text { SciELO }\end{array}$ & $\begin{array}{l}\text { Broska Júnior CA, Folchini AB, } \\
\text { Ruediger } R^{(7)} \text {. Cross-sectional } \\
(\mathrm{n}=3.112)\end{array}$ & $\begin{array}{l}\text { To compare differences in the elderly } \\
\text { and non-elderly profile of trauma vic- } \\
\text { tims. }\end{array}$ & $\begin{array}{l}\text { Falls and accidents are more frequent in the elderly/ } \\
\text { interpersonal violence in non elderly. }\end{array}$ \\
\hline $\begin{array}{l}2012 \\
\text { Brasil } \\
\text { SciELO }\end{array}$ & $\begin{array}{l}\text { Rodrigues J, Ciosak } \\
\mathrm{SI}^{(8)} \text {. Cross-sectional }(\mathrm{n}=261)\end{array}$ & $\begin{array}{l}\text { To identify risk factors for trauma in } \\
\text { the elderly. }\end{array}$ & $\begin{array}{l}\text { Female gender, having caregiver, continuous use of } \\
\text { medication and hearing problems increases the risk } \\
\text { of trauma.. }\end{array}$ \\
\hline $\begin{array}{l}2011 \\
\text { Brasil } \\
\text { LILACS }\end{array}$ & $\begin{array}{l}\text { Luz TCB, Malta DC, } \\
\text { Sá NNB, Silva MMA, Lima-Costa } \\
\text { MF }^{(9)} \text {. Cross-sectional }(n=25.201)\end{array}$ & $\begin{array}{l}\text { To compare individual attributes, types } \\
\text { of accidents and violence with assis- } \\
\text { tance in emergency services in Brazil. }\end{array}$ & $\begin{array}{l}\text { Among elderly occurred less contribution from alco- } \\
\text { hol, predominance of occurrences at home, greater } \\
\text { vulnerability to falls, family violence and pedestrians' } \\
\text { road traffic accidents. }\end{array}$ \\
\hline $\begin{array}{l}2011 \\
\text { Suécia/ } \\
\text { Austrália } \\
\text { CINAHL }\end{array}$ & $\begin{array}{l}\text { Saveman BI, Björnstig } \mathrm{U}^{(10)} \text {. } \\
\text { Cross-sectional }(\mathrm{n}=1.590)\end{array}$ & $\begin{array}{l}\text { To study the epidemiology of uninten- } \\
\text { tional injuries in Swedish elderly and } \\
\text { compare with data collected before. }\end{array}$ & $\begin{array}{l}\text { The fracture injury rate per } 1,000 \text { individuals in- } \\
\text { creased by } 40-50 \% \text { in Sweden, especially in older } \\
\text { age groups. }\end{array}$ \\
\hline $\begin{array}{l}2010 \\
\text { EUA } \\
\text { CINAHL }\end{array}$ & $\begin{array}{l}\text { u G, Baker } \mathrm{SP}^{(11)} \text {. Cross-sec- } \\
\text { onal ( } \mathrm{n}=\text { mortality rate } 2000-6+ \\
\text { orbidity rate } 2001-7)\end{array}$ & $\begin{array}{l}\text { ity and morbidity by inj } \\
\text { Americans with } 65 \text { years }\end{array}$ & $\begin{array}{l}\text { Injury mortality incr } \\
\text { and morbidity has ir } \\
\text { increase was due to r }\end{array}$ \\
\hline $\begin{array}{l}2010 \\
\text { Brasil } \\
\text { LILACS }\end{array}$ & $\begin{array}{l}\text { Lima MLC, Souza ER, Acioli } \\
\text { RML, Bezerra ED }{ }^{(12)} \text {. } \\
\text { Triangulation of methods }\end{array}$ & $\begin{array}{l}\text { To Perform diagnostic analysis of clini- } \\
\text { cal hospital services to emergency } \\
\text { care to the elderly population in five } \\
\text { capitals of Brazil. }\end{array}$ & $\begin{array}{l}\text { Health services that care for the elderly do not have } \\
\text { suitable profile and service necessary for the integral- } \\
\text { ity of care. }\end{array}$ \\
\hline $\begin{array}{l}2010 \\
\text { Brasil } \\
\text { LILACS }\end{array}$ & $\begin{array}{l}\text { Lima MLC, Souza ER, Lima } \\
\text { MLLT, Barreira AK, Bezerra ED, } \\
\text { Acioli RML }{ }^{(13)} \text {. } \\
\text { Triangulation of methods }\end{array}$ & $\begin{array}{l}\text { To perform diagnostic analysis of } \\
\text { healthcare systems in relation to the } \\
\text { elderly care victimized by accidents } \\
\text { and violence in Recife. }\end{array}$ & $\begin{array}{l}\text { Elderly care service is deficient in relation to clinical } \\
\text { protocols; notification; support to the elderly, caregiv- } \\
\text { ers and victimized; and professional training. }\end{array}$ \\
\hline $\begin{array}{l}2010 \\
\text { Brasil } \\
\text { LILACS }\end{array}$ & $\begin{array}{l}\text { Mello ALSF, Moysés SJ }{ }^{(14)} \text {. } \\
\text { Triangulation of methods }\end{array}$ & $\begin{array}{l}\text { To perform diagnostic analysis of pre- } \\
\text { hospitalized healthcare systems in the } \\
\text { elderly victims of accidents and vio- } \\
\text { lence. }\end{array}$ & $\begin{array}{l}\text { Consider the organization of data, flows, training } \\
\text { of professionals and programs for prevention, assis- } \\
\text { tance and rehabilitation for the elderly. }\end{array}$ \\
\hline $\begin{array}{l}2010 \\
\text { Brasil } \\
\text { LILACS }\end{array}$ & $\begin{array}{l}\text { Parreira JG, Soldá SC, } \\
\text { Perlingeiro JAG, Padovese CC, } \\
\text { Karakhanian WZ. } \\
\text { Assef JC(15). Prospective cohort } \\
(\mathrm{n}=2.075)\end{array}$ & $\begin{array}{l}\text { To define characteristics of trauma in } \\
\text { the elderly by comparison between } \\
\text { this group and the traumatized non } \\
\text { elderly. }\end{array}$ & $\begin{array}{l}\text { The elderly presented a higher frequency of falls from } \\
\text { own height, from associated diseases and intracranial } \\
\text { injuries }\end{array}$ \\
\hline $\begin{array}{l}2010 \\
\text { Brasil } \\
\text { LILACS }\end{array}$ & $\begin{array}{l}\text { Santos ER, Souza ER, Ribeiro AP, } \\
\text { Souza AMM, Lima RTS }{ }^{(16)} \text {. } \\
\text { Triangulation of methods }\end{array}$ & $\begin{array}{l}\text { To describe th } \\
\text { SUS network } \mathrm{f} \\
\text { dents or violen }\end{array}$ & $\begin{array}{l}\text { Barriers impairs the service of victims in the three } \\
\text { levels of the SUS network of Manaus. Data registry } \\
\text { and notification appear as one of the weakest points. }\end{array}$ \\
\hline $\begin{array}{l}2010 \\
\text { Brasil } \\
\text { LILACS }\end{array}$ & $\begin{array}{l}\text { Ribeiro AP, Barter EACP(17). } \\
\text { Triangulation of methods }\end{array}$ & $\begin{array}{l}\text { To describe the structure and charac- } \\
\text { terize the rehabilitation service of care } \\
\text { to the elderly victims of accidents and } \\
\text { violence. }\end{array}$ & $\begin{array}{l}\text { The implementation of policies that protect the elder- } \\
\text { ly presents a very unequal situation in rehabilitation } \\
\text { services of cities analyzed. }\end{array}$ \\
\hline
\end{tabular}




\begin{tabular}{|c|c|c|c|}
\hline $\begin{array}{l}\text { Year/ } \\
\text { country }\end{array}$ & $\begin{array}{l}\text { Authors } \\
\text { Design } \\
\text { Sample }\end{array}$ & Objectives & $\begin{array}{l}\text { Results } \\
\text { Conclusions }\end{array}$ \\
\hline $\begin{array}{l}2009 \\
\text { Brasil } \\
\text { SciELO }\end{array}$ & $\begin{array}{l}\text { Biazin DT, Rodrigues RAP }{ }^{(18)} \text {. } \\
\text { Cross-sectional }(\mathrm{n}=121)\end{array}$ & $\begin{array}{l}\text { To identify sociodemographic profile } \\
\text { of elderly traumatized and describe } \\
\text { the trauma types. }\end{array}$ & $\begin{array}{l}\text { Most of the elderly were married and male. The main } \\
\text { issues were falling and transportation accidents }\end{array}$ \\
\hline $\begin{array}{l}2009 \\
\text { EUA } \\
\text { PubMed }\end{array}$ & $\begin{array}{l}\text { Kent R, Trowbridge M, Lopez- } \\
\text { Valdes FJ, Ordoyo RH, SeguiGo- } \\
\text { mez } M^{(19)} \text {. Cross-sectional ( } n=10 \\
\text { years NASS - CDS) }\end{array}$ & $\begin{array}{l}\text { To estimate the number of deaths and } \\
\text { injuries in car occupants in the USA } \\
\text { associated with old age and the toler- } \\
\text { ance to the impact. }\end{array}$ & $\begin{array}{l}\text { Most of deaths were due to the greater fragility associ- } \\
\text { ated with the aging process and not just the greatest } \\
\text { fragility. }\end{array}$ \\
\hline $\begin{array}{l}2009 \\
\text { Singa- } \\
\text { pura } \\
\text { PubMed }\end{array}$ & $\begin{array}{l}\text { Yeo YYC, Lee SK, Lim CY, Quek } \\
\text { LS, Ooi SBS }{ }^{(20)} \text {. } \\
\text { Cross-sectional }(n=720)\end{array}$ & $\begin{array}{l}\text { To identify patterns of injury, risk fac- } \\
\text { tors and specific needs of the elderly to } \\
\text { direct prevention efforts. }\end{array}$ & $\begin{array}{l}\text { Domestic accidents were the most common, followed } \\
\text { by traffic accidents; and pedestrians' road traffic ac- } \\
\text { cidents, the most frequent accidents. }\end{array}$ \\
\hline $\begin{array}{l}2008 \\
\text { México } \\
\text { LILACS }\end{array}$ & $\begin{array}{l}\text { González GR, Snyder NS }{ }^{(21)} \text {. } \\
\text { Cross-sectional }(n=799)\end{array}$ & $\begin{array}{l}\text { To identify socio-demographic factors, } \\
\text { health and support related to acciden- } \\
\text { tal injury notification in elderly resi- } \\
\text { dents in four municipalities in Mexico }\end{array}$ & $\begin{array}{l}\text { The risk factors for injuries were: old age, work, exis- } \\
\text { tence of disease, use of medicines, poor perception of } \\
\text { health, alcohol use, inadequate family support, care } \\
\text { for others, being a woman and having no partner }\end{array}$ \\
\hline $\begin{array}{l}2008 \\
\text { Brasil } \\
\text { SciELO }\end{array}$ & $\begin{array}{l}\text { Katz M, Okuma MAA, Santos } \\
\text { ALG, Guglielmetti CLB, Sakaki } \\
\text { MH, Zumiotti AV(22). } \\
\text { Prospective cohort }(\mathrm{n}=28)\end{array}$ & $\begin{array}{l}\text { To determine the epidemiology of } \\
\text { high-energy injuries in the elderly and } \\
\text { analyze the characteristics linked to } \\
\text { trauma and its evolution throughout } \\
\text { the treatment }\end{array}$ & $\begin{array}{l}\text { Pedestrian's road traffic accident was the most prev- } \\
\text { alent mechanism in the elderly with high energy } \\
\text { trauma, resulting in fractures of the lower limbs The } \\
\text { majority of them evolved with some clinical compli- } \\
\text { cation. }\end{array}$ \\
\hline $\begin{array}{l}2008 \\
\text { Índia } \\
\text { PubMed }\end{array}$ & $\begin{array}{l}\text { Subhashraj K, } \\
\text { Ravindran } C^{(23)} \\
\text { Cross-sectional }(n=185)\end{array}$ & $\begin{array}{l}\text { To evaluate the incidence of maxil- } \\
\text { lofacial intervention in traumatized } \\
\text { elderly. }\end{array}$ & $\begin{array}{l}\text { Most of the injuries were due to accidents. The high- } \\
\text { est incidence was in the month of October and on } \\
\text { Saturdays }\end{array}$ \\
\hline $\begin{array}{l}2007 \\
\text { Canadá } \\
\text { CINAHL }\end{array}$ & $\begin{array}{l}\text { Jain } \mathrm{MK}^{(24)} \text {. } \\
\text { ive Cohort }(n=125)\end{array}$ & $\begin{array}{l}\text { To characterize the most common in- } \\
\text { juries and to identify the most frequent } \\
\text { complications in the traumatized el- } \\
\text { derly. }\end{array}$ & $\begin{array}{l}\text { More than } 50 \% \text { of deaths occurred in elderly, caused } \\
\text { by falls and traffic accidents. The most frequent com- } \\
\text { plications were: urinary infections and pneumonia }\end{array}$ \\
\hline $\begin{array}{l}2007 \\
\text { Austrália } \\
\text { PubMed }\end{array}$ & $\begin{array}{l}\text { Jamieson LM, Roberts-Thomson } \\
\mathrm{KF}^{(25)} \text {. Cross-sectional } \\
(\mathrm{n}=\text { rate of admission 1998-2005) }\end{array}$ & $\begin{array}{l}\text { To explore the rates of admission for } \\
\text { head trauma among elderly Austra- } \\
\text { lians according to risks indicated. }\end{array}$ & $\begin{array}{l}\text { The rate of admission for } \\
\text { times in the period. Most } \\
\text { wounds, superficial injuri }\end{array}$ \\
\hline $\begin{array}{l}2007 \\
\text { EUA } \\
\text { PubMed }\end{array}$ & $\begin{array}{l}\text { Pressley JC, Barlow B, Quitel } \\
\text { L, Jafri } A^{(26)} \text {. Prospective cohort } \\
(n=140)\end{array}$ & $\begin{array}{l}\text { To develop a model for injury preven- } \\
\text { tion in the elderly. }\end{array}$ & $\begin{array}{l}\text { The model of injury prevention identified injury risk } \\
\text { and improved access to screening and reducing the } \\
\text { risk factors }\end{array}$ \\
\hline $\begin{array}{l}2007 \\
\text { EUA } \\
\text { CINAHL }\end{array}$ & $\begin{array}{l}\text { Scheetz LJ, Zhang J, Kol- } \\
\text { assa JE(27). Prospective cohort } \\
(\mathrm{n}=7.883)\end{array}$ & $\begin{array}{l}\text { To identify variables in the accident } \\
\text { that could be used by emergency ser- } \\
\text { vices professionals to predict occur- } \\
\text { rence of injury in elderly }\end{array}$ & $\begin{array}{l}\text { We identified variables at the accident scene that } \\
\text { predicted the occurrence of injuries through statisti- } \\
\text { cal modeling based on performance elaborating two } \\
\text { decision models }\end{array}$ \\
\hline $\begin{array}{l}2006 \\
\text { Singa- } \\
\text { pura } \\
\text { PubMed }\end{array}$ & $\begin{array}{l}\text { Lee KK, Seow WT, Ng (28). } \\
\text { Prospective cohort }(n=528)\end{array}$ & $\begin{array}{l}\text { To identify the demographic and clini- } \\
\text { cal profile of adult patients with severe } \\
\text { TBI in Singapore }\end{array}$ & $\begin{array}{l}\text { Accidents and falls were the main causes. They identi- } \\
\text { fied three high-risk groups: young adults, elderly and } \\
\text { foreigners }\end{array}$ \\
\hline $\begin{array}{l}2006 \\
\text { Austrália } \\
\text { PubMed }\end{array}$ & $\begin{array}{l}\text { Yee WY, Cameron PA, Bailey } \\
\text { MJ }^{(29)} \text {. Transversal }(n=1.539)\end{array}$ & $\begin{array}{l}\text { investigate the pattern of injury in } \\
\text { derly people involved in traffic ac- } \\
\text { dents. }\end{array}$ & $\begin{array}{l}\text { The mortality rate of the elde } \\
\text { younger group, and higher ra } \\
\text { rax: rib fractures, flail chest at }\end{array}$ \\
\hline $\begin{array}{l}2006 \\
\text { Brasil } \\
\text { SciELO }\end{array}$ & $\begin{array}{l}\text { Mathias TAF, Mello Jo } \\
\text { Andrade OG }{ }^{(30)} \text {. Retro } \\
\text { cohort (n=IM: 1979-9 } \\
\text { 1995-1998) }\end{array}$ & $\begin{array}{l}\text { To analyze mortality and hospital mor- } \\
\text { bidity by external causes in elderly } \\
\text { Maringa resident population }\end{array}$ & $\begin{array}{l}\text { In the last three years, from traffic accidents, pedes- } \\
\text { trian accidents were the most frequent cause of death } \\
\text { for both men and for women }\end{array}$ \\
\hline $\begin{array}{l}2005 \\
\text { EUA } \\
\text { CINAHL }\end{array}$ & $\begin{array}{l}\text { Augenstein J, Digges K, Bahouth } \\
\text { G, Dalmotas D, Perdeck } \\
\text { E, Stratton J }{ }^{(31)} \text {. } \\
\text { Cross-sectional }(n=\text { data from } \\
\text { NASS/CDS 1997-2003) }\end{array}$ & $\begin{array}{l}\text { To investigate the occurrence of inju- } \\
\text { ries in the occupants of vehicles using } \\
\text { sit belt, stratified by age. }\end{array}$ & $\begin{array}{l}\text { Older occupants are more involved in frontal minor } \\
\text { impacts than younger people. At the same time, the } \\
\text { likelihood of harm is greater than among younger }\end{array}$ \\
\hline $\begin{array}{l}2005 \\
\text { EUA } \\
\text { PubMed }\end{array}$ & $\begin{array}{l}\text { Kent } \mathrm{R} \text {, Henary } \mathrm{B} \text {, Matsuoka } \mathrm{F}^{(32)} \text {. } \\
\text { Retrospective Cohort } \\
\text { ( } \mathrm{n}=\text { fatal accidents NASS/ } \\
\text { CDS/1992 to } 2002-\text { FARS/2002) }\end{array}$ & $\begin{array}{l}\text { To identify the region of the body af- } \\
\text { fected, the seriousness and the circum- } \\
\text { stances surrounding accidents involv- } \\
\text { ing elderly drivers in the USA. }\end{array}$ & $\begin{array}{l}\text { The mortality rate increased with age. The elderly are } \\
\text { more likely to die of chest injury. Any weakness or a } \\
\text { condition of previous health interfered with } 50 \% \text { of } \\
\text { deaths in elderly }\end{array}$ \\
\hline $\begin{array}{l}2005 \\
\text { EUA } \\
\text { CINAHL }\end{array}$ & $\begin{array}{l}\text { Scheetz LJ }{ }^{(33)} \text {. } \\
\text { Cross-sectional }(n=1.478)\end{array}$ & $\begin{array}{l}\text { To compare the relationship between } \\
\text { type of injury, comorbidities, age, se- } \\
\text { verity and survival of elderly injured } \\
\text { in Trauma Centers (TC) with those in } \\
\text { other services (NTC). }\end{array}$ & $\begin{array}{l}\text { Patients admitted to TC showed greater severity, while } \\
\text { those in NTC had higher proportion of soft tissue inju- } \\
\text { ries. Attention is needed in screening elderly trauma- } \\
\text { tized by risk of hidden injury. }\end{array}$ \\
\hline
\end{tabular}




\begin{tabular}{|c|c|c|c|}
\hline $\begin{array}{l}\text { Year/ } \\
\text { country }\end{array}$ & $\begin{array}{l}\text { Authors } \\
\text { Design } \\
\text { Sample }\end{array}$ & Objectives & $\begin{array}{l}\text { Results } \\
\text { Conclusions }\end{array}$ \\
\hline $\begin{array}{l}2004 \\
\text { EUA } \\
\text { PubMed }\end{array}$ & $\begin{array}{l}\text { Braver ER, Trempel } \\
\mathrm{RE}^{\left({ }^{(34)} \cdot \text { Cross-sectional }\right.} \\
(\mathrm{n}=\text { fatal accidents and non-fatal } \\
\text { GES/FARS/NPTS } 1993-97)\end{array}$ & $\begin{array}{l}\text { To investigate the risks of elderly driv- } \\
\text { ers on the roads compared to other us- } \\
\text { ers, such as pedestrians, passenger of } \\
\text { the same vehicle and other vehicles. }\end{array}$ & $\begin{array}{l}\text { Exposure to accidents and the frequency of injuries in } \\
\text { the elderly were higher in crashes of low severity. The } \\
\text { chest was the most injured body region in the elderly. }\end{array}$ \\
\hline $\begin{array}{l}2004 \\
\text { Brasil } \\
\text { LILACS }\end{array}$ & $\begin{array}{l}\text { Gawryszews VP, Mello Jorge } \\
\text { MHP, Koizumi MS }{ }^{(35)} \text {. } \\
\text { Cross-sectional } \\
\text { ( } \mathrm{n}=13.383 \text { deaths }+ \\
87.177 \text { admissions) } \\
\end{array}$ & $\begin{array}{l}\text { To analyze the morbimortality by ex- } \\
\text { ternal causes in individuals with } 60 \\
\text { years or more in Brazil. }\end{array}$ & $\begin{array}{l}\text { The mortality coefficient from external causes in } \\
\text { the elderly is higher than in the general population. } \\
\text { Regarding morbidity, falls are the leading cause of } \\
\text { hospitalizations. Regarding injuries, fractures were } \\
\text { highlighted. }\end{array}$ \\
\hline $\begin{array}{l}2003 \\
\text { Canadá } \\
\text { PubMed }\end{array}$ & 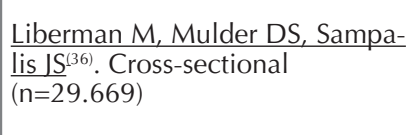 & $\begin{array}{l}\text { To identify the profile of the patients } \\
\text { seen in four tertiary trauma centers in } \\
\text { Quebec, the nature of their injuries } \\
\text { and triage protocols. }\end{array}$ & $\begin{array}{l}\text { The proportion of elderly injured in falls and inju- } \\
\text { ries with isolated members of low gravity in tertiary } \\
\text { trauma centers is high. Review of prehospital triage } \\
\text { protocols should be discussed. }\end{array}$ \\
\hline $\begin{array}{l}2003 \\
\text { Brasil } \\
\text { LILACS }\end{array}$ & $\begin{array}{l}\text { Souza RKT, Soares DFPP, Math- } \\
\text { ias TAF, Andrade OG, Santana } \\
\text { RG }^{(37)} \text {. Prospective cohort } \\
(\mathrm{n}=31)\end{array}$ & $\begin{array}{l}\text { To describe the profile of the elderly } \\
\text { victims of traffic accident and analyze } \\
\text { the circumstances of the accident and } \\
\text { its impact in the lives of the elderly } \\
\text { and their families }\end{array}$ & $\begin{array}{l}\text { Most victims were male and pedestrian. All nonfa- } \\
\text { tal victims reestablished their functional capacity for } \\
\text { daily activities. }\end{array}$ \\
\hline
\end{tabular}

From the analyzed publications, 14 (43.7\%) are Brazilian studies ${ }^{(7-9,12-18,22,30,35,37)}$. Of these, six were developed by researchers at the Latin American Center for the Study of Violence and Jorge Careli Health (CLAVES) from the National School of Public Health Sergio Arouca ${ }^{(9,12-14,16-17)}$. Another country that had a high percentage of studies were the United States, with a total of nine publications $(28.1 \%)^{(6,11,19,26-27,31-34)}$.

As to the method adopted in the selected studies, five (15.6\%) were based on the principles of triangulation method and the others are transversal observational studies (56.2\%) and prospective (15.6\%) and retrospective (12.6\%) cohorts.

The analysis of objectives, results and conclusions of the 32 selected studies allowed the grouping into three categories: epidemiological data from traffic accidents involving elderly, traffic accidents with elderly pedestrians; and trauma care for the elderly.

\section{EPIDEMIOLOGICAL DATA FROM TRAFFIC ACCIDENTS INVOLVING ELDERLY}

Because traffic accidents constitute a public health problem worldwide, we found studies from different countries addressing this issue.

In the United States, we identified an increase in mortality and morbidity from traumatic injury among Americans aged 65 years or more, verifying that mortality from unintentional injury increased by $3 \%$ between 2000 and 2006, while the morbidity increased by 7\% between 2001 and 2007 . There was a noteworthy increase of $145 \%$ in the mortality rate due to motorcycle accidents and, in relation to morbidity, motorcycle accidents and bicycle increased $86 \%$ and $24 \%$, respectively ${ }^{(11)}$.

Another US study with data from fatal and non-fatal accidents analyzed the shared risks of older drivers with other users and found that, in relation to fatal accidents, the impact was an increase in mortality rates among occupants in the condition of passengers, who were also elderly. In non-fatal accidents, drivers with 75 years or more had a relative risk of 1.1 for collision accidents with injuries to occupants of other vehicles compared to younger drivers ${ }^{(34)}$.

In Singapore, a study of traumatized elderly to identify patterns of injury, specific risk factors and the needs of accident victims, found that traffic accidents were the second leading cause of trauma in that population ${ }^{(20)}$.

Research conducted in India to assess the incidence of maxillofacial trauma intervention among elderly showed that $79.4 \%$ of the injuries resulted from traffic accidents and those aged 60 to 69 years were injured more often than older ones ${ }^{(24)}$.

In Brazil, transportation accidents in 2000 led to mortality from external causes among people aged 60 years and older, representing $27.5 \%$ of total fatalities. This proportion was higher than that calculated for the general population, in which these causes accounted for $17.4 \%$ of deaths from external causes in the country that year ${ }^{(23)}$.

Another Brazilian study that evaluated 121 elderly people 60-74 years old and their caregivers in Londrina showed that $25.6 \%$ of the injuries suffered were caused by traffic accidents. As consequence of trauma, it occurred one to three injuries, and $9.1 \%$ of the elderly patients $\operatorname{died}^{(18)}$.

Considering the location of the injuries, a cross-sectional study conducted in 2006 with Swedish elderly aimed at studying the epidemiology of unintentional injuries and compare the incidence observed two decades earlier, they noted that the rate of injury and fracture per 1,000 people increased by about 40 to $50 \%$, mainly in the older age groups, fractures being the most common extremity injuries ${ }^{(10)}$.

Similarly, the characterization of injuries in elderly $\mathrm{Ca}^{-}$ nadians traumatized in accidents in a period of three years, also considering the complications, found that fractures were the most common injuries, urinary infections and aspiration pneumonia the most frequent complication ${ }^{(24)}$.

In Mexico, a cross-sectional study with 799 elderly in the period from June 2004 to August 2005 to identify fac- 
tors associated with notification of accidental injuries, they found that upper and lower extremities were the regions most affected by trauma ${ }^{(21)}$.

In Brazil, data from traumas and injuries resulting from traffic accidents, obtained through analysis of 13383 deaths and 87177 hospitalization from external causes in people aged 60 and over in the National Health System (SUS) in 2000, showed that fractures were the majority (45.0\%), mainly located in the lower limbs (29.2\%), with emphasis on femur fractures $(19.3 \%)$, followed by head injuries (14.4\%), by fractures of upper limbs (12.1\%) and multiple fractures (11.9\%) ${ }^{(35)}$.

In the United States of America, investigation on the occurrence of injury as a function of age, for the occupants who used seatbelts in the period 1997-2003, found that the frontal and lateral collisions, the chest was the most frequently injured body region in elderly occupants. It was recommended that security projects for the elderly to include seatbelts with low limits of force, distributing the load more evenly over the breast ${ }^{(31)}$.

Likewise, the determination of injuries patterns in Australian elderly people involved in automobile collisions in a two-year period showed that traumatized had a higher rate of chest injuries, finding in this region of the body the most common three injuries corresponding to $23.5 \%$ of rib fractures, $9.5 \%$ of flail chest and $5.9 \%$ of fractures of the sternum. The overall mortality rate observed in the elderly group was nearly twice that found in the younger group ${ }^{(29)}$.

Traumatic brain injury was present in other studies. The injury rates among elderly patients hospitalized at the Australian Institute of Health and Welfare increased 1.4 times from 1998 to 1999 and from 2004 to 2005, noting that elderly 85 years and older were 10.8 times the rate found among who had age between 60 and 64 years $^{(25)}$.

In Singapore, the TBI remains a major public health problem and a condition indicative of significant morbidity and mortality, with traffic accidents and falls the main causes of this type of injury in that country ${ }^{(28)}$.

In Brazil, a study conducted in the southeastern region aiming to define the characteristics of trauma in the elderly by comparing the variables between this group and the nonelderly traumatized observed that some injuries were more common in the elderly, such as subdural hematoma, subarachnoid hemorrhages and cerebral contusions ${ }^{(15)}$.

Regarding the vulnerability of the elderly to traffic accidents, international studies state that increasing age and severity of injury are predictors of complications and mortality. Increasing age reduces tolerance to shock in the collision, and the fragility or preexisting health problem may pose a risk of death up to $50 \%$ greater in the older group $^{(19,24,32)}$.

In the studies selected, accidents involving elderly pedestrians were fairly addressed and it became imperative to describe them, so you can ask about social and environmental changes required to reduce these occurrences.

\section{TRAFFIC ACCIDENTS WITH ELDERLY PEDESTRIANS}

In the USA a study that examined accidents involving pedestrians in the period 2000-2010, aiming to characterize the population and the pattern of injury, it was observed that $18.7 \%$ of the victims were elderly and of these $39 \%$ were 80 years and older, wherein the mortality rate for elderly patients was more than twice that of non-elderly patients ${ }^{(6)}$.

In Brazil, the profile of events to external causes in the elderly differs in some aspects from what occurs among younger, with a greater vulnerability to pedestrian traffic accidents, calling attention to the high proportion of deaths from this cause $(48.2 \%)^{(7,9,35)}$.

Considering this issue, research conducted in Maringa associated factors as responsible for accidents limitations of aging as the most restricted mobility, lack of attention, visual and hearing difficulties, among other deficiencies from aging, as well as the time of the traffic lights on the roads, which not always allow the completion of the crossing at the scheduled time. However, a portion of the pedestrian elderly traffic accidents were attributed to the carelessness of drivers ${ }^{(37)}$.

Research conducted in Brazil to analyze morbidity and mortality from external causes in elderly residents of a city in the south of the country found that between the age group of 60 and 64 years pedestrian collisions had coefficient of 22.7 deaths per 100,000 for men and 5.6 deaths per 100,000 for women. However, among those aged 85 years and over this value was 3.2 deaths per 100,000 males $^{(30)}$.

Another national study conducted in Sao Paulo to determine the epidemiology of injuries resulting from highenergy trauma in the elderly population and analyze the specific characteristics linked to trauma, as well as evolvement throughout treatment, found that the most prevalent mechanism of injury was collision, resulting mainly in fractures of the lower limbs. The length of hospitalization was higher in patients of younger age groups, and 90\% had some type of medical complication after orthopedic surgery, and age alone acting as a positive predictive factor for the occurrence of complications in polytrauma ${ }^{(22)}$.

\section{Trauma CARE FOR THE ELDERLY}

The increasing number of elderly in the population and a more active life they have developed, including conducting professional activities, have provided increased exposure and hence enabled the increased occurrence of trauma by traffic accident in this group ${ }^{(9.1222)}$.

National and international studies claim that the occurrence of common aging factors such as frailty, comorbidities, polypharmacy, functional, physical and cognitive limitations make traumatic injuries more complicated to prevent among the elderly. For this reason, the evaluation protocols of trauma among people over the age of 60 must be considered with special attention, since the injuries can be hidden, increasing the risk of fatal outcome $^{(7,21-22,26-27,33,36)}$.

In Canada, a study investigated the records of trauma in a period of seven years and analyzed the nature of the injuries and the need for modification of screening protocols recommended in specialized geriatric assessment and suitability of these documents for conducting appropriate referral to proper centers ${ }^{(36)}$. 
In this sense, national studies have reported the occurrence of problems in the early diagnosis of injuries in the traumatized elderly and considering indispensable the presence of professionals with backgrounds in gerontology teams in trauma care, recommending urgent training of professionals specialized services for the identification, performance, referral and proper monitoring of these cases ${ }^{(12,14-15)}$.

In 2009, a diagnostic analysis in clinical hospital services and emergency for traumatized in five Brazilian capitals was conducted, elderly care with reference to some public policies such as the National Policy for Reduction of Morbidity and Mortality from Accidents and Violence, National Policy of Emergency Care, Ordinance No. 2048-GM/MS20, the Elderly Statute and the National Health Policy for the Elderly. The results showed that none of the capitals studied met all requirements recommended by policy, showing deficiencies in structure and organization to keep a companion, failures in referring to referral services in specific clinical protocols, in case report forms, in support of the elderly on the job training and the definition of flow for this population ${ }^{(12)}$.

Study conducted in Curitiba, focusing on the general conditions of infrastructure, planning and support for mobile and fixed pre-hospital care to victimized elderly care caused by accidents and violence, concluded that this service is still nascent treatment with the actions developed in the 14 services investigated in that city. The authors observed no specific plan or definition of flows for elderly care that is in this situation, missing preventive protocols approach, also occurring deficiency in reported cases ${ }^{(14)}$.

In Recife, another diagnostic analysis based on the guidelines of National Policy for Reduction of Morbidity and Mortality from Accidents and Violence and the National Health Policy for the Elderly showed that these guidelines are only partially covered, and poor compliance in relation to various aspects such as protocols clinical, notifying, support for elderly, caregivers and victimizers, and job training ${ }^{(13)}$.

In this regard, the elderly care of accident victim and violence in Manaus revealed scarcity of hospital beds and intensive care units for treatment of the elderly. They also made evident the need for training of health professionals and medical specialists to monitor these elderly patients hospitalized for trauma ${ }^{(16)}$.

Regarding rehabilitation care to the elderly, victims of accidents and violence, a research conducted in five Brazilian cities, based on the National Policy for Reduction of Morbidity and Mortality from Accidents and Violence in the Elderly Statute and National Health Politics for the Elderly, pointed out that this care shows weaknesses in the implementation of public policies considered. Few units have the resources to respond to the specific needs of the elderly victims of these issues ${ }^{(17)}$.

\section{DISCUSSION}

The selected studies on trauma caused by traffic accident in the elderly were, mostly, studies conducted in Brazil. It is believed that the importance given to this topic by CLAVES contributed to this fact, from the selected Brazilian studies, six were conducted for this study group and discuss accidents and violence with the elderly based on established policies in the country, demonstrating the concern of these researchers with the problem of violence and accidents in this age group in Brazil. As for the number of north-American publications, the Committee on Trauma, created in 1922 by the American College of Surgeons, has recognized this event as aggravation and proceeded to propose prevention and control, in search of improved care.

Regarding study design, the majority of studies were observational, mostly cross-sectional, exclusively using information from databases of trauma, which demonstrates the importance of adequate registry data on trauma for epidemiological analysis of these events. However, it is emphasized that the difficulty of cross-sectional studies is to establish causal relationships. Perhaps, for this reason, there is a lack of studies identifying risk factors that can prevent trauma in the elderly ${ }^{(8)}$.

Based on the main results and conclusions of the studies showed, there were similar issues related to trauma by traffic accident involving elderly people in different countries, including the increased incidence, the location of the most prevalent injuries, the severity of pedestrian traffic accidents with increased mortality and complications.

Regarding the increase in the incidence of injuries resulting from traffic accidents in the elderly population, it is observed that even in a developed country such as the United States, there was an increase in traffic accidents, especially those involving motorcycles, showing a similar reality found in Brazil. Based on the above, the need for investigation of causes is confirmed, so that there may be planning and implementation of stricter measures to control and prevent these issues in different countries. It appears, therefore, that accidents with elderly are important events because of the greater vulnerability of this segment of the population, which can result in injuries of varying severity ${ }^{(30)}$.

Considering the most prevalent types of injury among the elderly victims in traffic, the injuries of the extremities were highlighted. Thus, it emphasizes the importance of these injuries, although they alone cannot be life threatening for the injured, on the other hand, they are responsible for most of the immobilizations and, consequently, the loss of functional independence of these people, even if this is temporary.

Other types of injuries frequently cited in publications were the traumas of the thorax and cranioencephalic, which were significant for being related to higher mortality, as well as by increasing the retention of older people in intensive care units. Through the discussions, it is noticed that the elderly, although they are not the group most victimized by traffic accidents represent the most serious, both for the physiological changes that occur during aging and by the seriousness of the injuries caused by these events. Due to all it has been mentioned, it is necessary to investigate causal factors and possible prevention measures for this population. 
A study conducted in Manaus, with the elderly population who were victims of accident and violence, found that little has been done in the field of prevention, noting that the registry of data and notification appeared as the weakest points in the three levels of care ${ }^{(16)}$.

The epidemiological data obtained demonstrated the importance of traffic accidents for the elderly, allowing us to infer the severity of such events pose to reaching a healthy old age, noting the existence of similar aspects in different countries, such as increased mortality from this cause among the elderly, especially among the oldest ones, reaching, in some countries, similar number of occurrences found among young people.

There have also been other aggravating factors, such as the elderly living with permanent disabilities after the accident and the difficulty of preventing such occurrences, due to the multifactorial nature of the event. The elderly, due to accident, can suffer an impairment in their quality of life with the possibility of worsening, as a result of other changes due to aging, since the impact of the accident in everyday life tends to reduce integration into society. Also, because of the vulnerability, the chances of economic costs in this phase of life are even greater, as determined by the probability of a longer hospital stay, with greater chance of complications $^{(37)}$.

The vulnerability of the elderly to the traffic accident is undeniable, and in the condition of pedestrian, the vulnerability is accentuated by the greater exposure of the victim at the time of the collision. However, the protective measures in this direction are timid and limited ${ }^{(37)}$, and yet no country requires that the front of the vehicle are designed to minimize injury to pedestrians ${ }^{(3)}$.

The studies have also discussed issues related to the care of these patients, which presents specificities. In this sense, Brazilian studies of situational analysis for diagnostic attention to accidents and violence services, based on the established policies in the country, found that the services do not fully meet the recommended measures.

Study that addressed the inclusion of the topic violence against elderly in Brazilian public policies on health care claim that the early years of this century have been presented as a period of creation, coordination, integration and consolidation of plans, safety nets and guarantees of the rights of elderly, a population that grows rapidly and requires monitoring to ensure a long and healthy life ${ }^{(4)}$.

In this sense, the importance of effective participation in nursing care for the elderly is emphasized - both in primary care, by promoting healthy behaviors and safe environments to establish mechanisms that encourage the disclosure of educational information about biopsychosocial aspects of aging - as well as in pre-hospital and in-hospital care to elderly victims of accidents and violence, monitoring these events and participating in the interdisciplinary and inter-sectorial victim care with trained professionals in the fields of geriatrics and gerontology and provision of services.

It is believed that the aspects listed on this type of care showed the severity of the problem, especially considering that this population is already experiencing, on a daily basis, other losses associated with aging. Therefore, the planning and implementation of actions aimed at valuing the elderly are urgently needed, considering the population growth of this age group, as well as their importance to the economy.

\section{CONCLUSION}

Epidemiological data of traffic accidents involving the elderly showed an increased incidence of trauma for this reason, in most countries studied in the past ten years. These studies showed that most victims of traffic accidents are pedestrians and the elderly, mainly the oldest portion of this age group are more vulnerable.

Currently, the traffic in cities is more risky, hence elderly pedestrians become more vulnerable due to the limitations of aging, but also due to lack of attention from drivers and inadequate urban planning, among other factors. Therefore, it is urgent to invest in efforts to prevent and reduce deaths and injuries from accidents in this population, creating appropriate strategies to minimize such occurrences.

It is urgent to build urban spaces, which are friendlier for elderly, as well as investment in the culture of solidarity, thinking of a society for all. Safe mobility is a fundamental right, and to ensure that, some measures need to be discussed, such as: appropriate traffic lights, especially in the busiest Avenues or streets; protected bus stops where access in and out of collective transportation are provided; accessible and readable information, considering the limited vision of aging; closer monitoring of traffic in relation to speed limits; and the adoption of educational and punitive measures aimed at combating these accidents and to protect vulnerable street users.

In the general context, the results drew attention to the possibilities for prevention, considering that traffic accidents can be avoided with the use of simple measures, representing a challenge for nurses in health promotion through guidance and self-care programs for seniors and their families.

The publications analyzed discussed the elderly trauma care, highlighting the need for adaptation of protocols and the presence of professionals with specialized training in gerontology in trauma care services. Studies of diagnostic analysis conducted in Brazil have shown that elderly trauma care has shortcomings, not being followed the precepts recommended by the public policies established in the country. Therefore, training of human resources for this service is essential, highlighting the preparation of nurses to care for this population, as they are able to evaluate the risks to the injured elderly treated in emergency in the country and their consequent monitoring services.

Thus, there is a need to involve society in general, including commitment of managers and professionals, educational institutions and professional associations in the health field, as well as security and communication agencies so that, the elderly is seen in their specific features and weaknesses, being recognized as vulnerable to traffic accidents, especially in the condition of the pedestrian. 
RESUMO

Objetivo: Descrever o conhecimento científico produzido sobre o trauma em idosos por acidentes de trânsito nas publicações da área de saúde. Método: Revisão integrativa a partir de publicações levantadas nas bases de dados LILACS, SciELO, PubMed e CINHAL, no período de 2003 a 2013. Utilizou-se a combinação dos descritores ferimentos, lesões e acidentes, nas línguas inglesa, portuguesa e espanhola. Resultados: Foram selecionados 32 estudos. $\mathrm{Na}$ análise temática emergiram três categorias: dados epidemiológicos dos acidentes de trânsito com idosos, os acidentes de trânsito com idosos pedestres e o atendimento ao idoso traumatizado. Observou-se aumento da incidência desse trauma na maioria dos países e os pedestres representam grande parte das vítimas. Dentre estes, os idosos são o grupo mais vulnerável. Conclusão: As publicações evidenciaram ainda o atendimento ao idoso traumatizado, sugerindo a necessidade de existência de protocolos e de profissionais com formação em gerontologia nos serviços especializados de atendimento ao trauma.

\section{DESCRITORES}

Idoso; Ferimentos e Lesões; Acidentes de Trânsito; Enfermagem; Revisão.

\section{RESUMEN}

Objetivo: Describir el conocimiento científico producido acerca del trauma en ancianos por accidentes de tránsito en las publicaciones del área de salud. Método: Revisión integradora a partir de publicaciones recogidas de las bases de datos LILACS, SciELO, PubMed y CINHAL, en el período de 2003 a 2013. Se utilizó la combinación de los descriptores herimientos, lesiones y accidentes, en las lenguas inglesa, portuguesa y española. Resultados: Fueron seleccionados 32 estudios. En el análisis temático emergieron tres categorías: datos epidemiológicos de los accidentes de tránsito con ancianos, los accidentes de tránsito con peatones ancianos y la atención al anciano traumatizado. Se advirtió un incremento de la incidencia de ese trauma en la mayoría de los países y los peatones representan gran parte de las víctimas. Entre ellos, las personas mayores son el grupo más vulnerable. Conclusión: Las publicaciones evidenciaron asimismo la atención al añoso traumatizado, sugiriendo la necesidad de existencia de protocolos y de profesionales con formación en gerontología en los servicios especializados de atención al trauma.

\section{DESCRIPTORES}

Anciano; Heridas y Traumatismos; Accidentes de Tránsito; Enfermería; Revisión.

\section{REFERENCES}

1. Lebrão ML. O envelhecimento no Brasil: aspectos da transição demográfica e epidemiológica. Saúde Coletiva [Internet]. 2007 [citado 2013 out. 10];4(17):135-40. http://www.prefeitura.sp.gov.br/cidade/secretarias/upload/saude/arquivos/pessoaidosa/EnvelhecimentoBrasilTransicao-MLLebrao-SaudeColetiva2007.pdf

2. Parreira JG, Farrath S, Soldá SC, Perlingeiro JAG, Assef JC. Análise comparativa das características do trauma entre idosos com idade superior e inferior a 80 anos. Rev Col Bras Cir [Internet]. 2013 [citado 2014 out. 5];40(4):269-74. Disponível em: http://www.scielo.br/pdf/ rcbc/v40n4/v40n4a03.pdf

3. Peden M, Scurfield R, Sleet D, Mohan D, Hyder A, Jarawan E, et al. Informe mundial sobre prevención de los traumatismos causados por el tránsito. Washington: OPAS; 2004.

4. Souza ER, Minayo MCS. Inserção do tema violência contra a pessoa idosa nas políticas públicas de atenção à saúde no Brasil. Ciênc Saúde Coletiva [Internet]. 2010 [citado 2013 set. 6];15(6):2659-2668. Disponível em: http://www.scielo.br/pdf/csc/v15n6/a02v15n6.pdf

5. Whittemore R, Knafl K. The integrative review: updated methodology. J Adv Nurs. 2005;52(5):546-53.

6. Mcelroy LM, Juern JJ, Bertleson A, Xiang Q, Szabo A, Weigelt J. A single urban center experience with adult pedestrians struck by motor vehicles. WMJ. 2013;112(3):117-22.

7. Broska Junior CA, Folchini ABD, Ruediger RR. Estudo comparativo entre o trauma em idosos e não idosos atendidos em um Hospital Universitário de Curitiba. Rev Col Bras Cir [Internet]. 2013 [citado 2013 ago. 30];40(4):281-6. Disponível em: http://www.scielo.br/pdf/ rcbc/v40n4/v40n4a05.pdf

8. Rodrigues ], Ciosak SI. Elderly victims of trauma: analysis of the risk factors. Rev Esc Enferm USP [Internet]. 2012 [cited 2013 Aug 6];46(6):1400-5. Available from: http://www.scielo.br/pdf/reeusp/v46n6/en_17.pdf

9. Luz TCB, Malta DC, Sá NNB, Silva MMA, Lima-Costa MF. Violências e acidentes entre adultos mais velhos em comparação aos mais jovens: evidências do Sistema de Vigilância de Violências e Acidentes (VIVA), Brasil. Cad Saúde Pública [Internet]. 2011 [citado 2013 ago. 6];27(11):2135-42. Disponível em: http://www.scielo.br/pdf/csp/v27n11/07.pdf

10. Saveman BI, Björnstig U. Unintentional injuries among older adults in northern Sweden - a one-year population-based study. Scand J Caring Sci. 2011;25(1):185-93.

11. Hu G, Baker SP. Recent increases in fatal and non-fatal injury among people aged 65 years and over in the USA. Inj Prev. 2010;16(1):26-30.

12. Lima MLC, Souza ER, Acioli RML, Bezerra ED. Análise dos serviços hospitalares clínicos aos idosos vítimas de acidentes e violências. Ciênc Saúde Coletiva [Internet]. 2010 [citado 2013 ago. 6];15(6):2687-97. Disponível em: http://www.scielo.br/pdf/csc/v15n6/a07v15n6.pdf.

13. Lima MLC, Souza ER, Lima MLLT, Barreira AK, Bezerra ED, Acioli RML. Assistência à saúde dos idosos vítimas de acidentes e violência: uma análise da rede de serviços SUS no Recife (PE, Brasil). Ciênc Saúde Coletiva [Internet]. 2010 [citado 2013 ago. 6];15(6):2677-86. Disponível em: http://www.scielo.br/pdf/csc/v15n6/a06v15n6.pdf

14. Mello ALSF, Moysés SJ. Análise diagnóstica do atendimento pré-hospitalar para acidentes e violências contra idosos em Curitiba (PR, Brasil). Ciênc Saúde Coletiva. [Internet]. 2010 [citado 2013 ago. 6];15(6):2709-18. Disponível em: http://www.scielo.br/pdf/csc/v15n6/ a09v15n6.pdf 
15. Parreira JG, Soldá SC, Perlingeiro JAG, Padovese CC, Karakhanian WZ, Assef JC. Análise comparativa das características do trauma entre pacientes idosos e não idosos. Rev Assoc Med Bras [Internet]. 2010 [citado 2013 ago. 6];56(5):541-6. Disponível em: http://www.scielo. $\mathrm{br} / \mathrm{pdf} / \mathrm{ramb} / \mathrm{v} 56 \mathrm{n} 5 / \mathrm{v} 56 \mathrm{n} 5 \mathrm{a} 14 . \mathrm{pdf}$

16. Santos ER, Souza ER, Ribeiro AP, Souza AMM, Lima RTS. Cenário do atendimento aos agravos provocados por acidentes e violência contra idosos na rede SUS de Manaus (AM, Brasil). Ciênc Saúde Coletiva [Internet]. 2010 [citado 2013 ago. 6];15(6):2741-52. Disponível em: http://www.scielo.br/pdf/csc/v15n6/a12v15n6.pdf

17. Ribeiro AP, Barter EACP. Atendimento de reabilitação à pessoa idosa vítima de acidentes e violência em distintas regiões do Brasil. Ciênc Saúde Coletiva [Internet]. 2010 [cited 2013 ago. 6];15(6):2729-40. Disponível em: http://www.scielo.br/pdf/csc/v15n6/a11v15n6.pdf

18. Biazin DT, Rodrigues RAP. Profile of elderly patients who suffered trauma in Londrina - Paraná. Rev Esc Enferm USP. 2009;43(3):602-8.

19. Kent R, Trowbridge M, Lopez-Valdes FJ, Ordoyo RH, Segui-Gomez M. How many people are injured and killed as a result of aging? Frailty, fragility, and the elderly risk-exposure tradeoff assessed via a risk saturation model. Ann Adv Automot Med [Internet]. 2009 [cited 2013 Sept 6];53:41-50. Available from: http://www.ncbi.nlm.nih.gov/pmc/articles/PMC3256801/

20. Yeo YYC, Lee SK, Lim CY, Quek LS, Ooi SBS. A review of elderly injuries seen in a Singapore emergency department. Singapore Med J [Internet]. 2009 [cited 2013 Sept 6];50(3):278-83. Available from: http://smj.sma.org.sg/5003/5003a6.pdf

21. González MGR, Snyder NS. Lesiones accidentales en adultos mayores: un reto para los sistemas de salud. Salud Pública Méx [Internet]. 2008 [citado 2013 ago. 6];50(6):463-71. Disponible en: http://www.scielosp.org/pdf/spm/v50n6/07.pdf

22. Katz M, Okuma MAA, Santos ALG, Guglielmetti CLB, Sakaki MH, Zumiotti AV. Epidemiologia das lesões traumáticas de alta energia em idosos. Acta Ortop Bras [Internet]. 2008 [citado 2013 ago. 6];16(5):279-83. Disponível em: http://www.scielo.br/pdf/aob/v16n5/v16n5a05.pdf

23. Subhashraj K, Ravindran C. Maxillofacial intervention in trauma patients aged 60 years and older. Indianas J Dent Res. 2008;19(2):109-11.

24. Gowing R, Jain MK. Injury patterns and outcomes associated with elderly trauma victims in Kingston, Ontario. Can J Surg. 2007;50(6):437-44.

25. Jamieson LM, Roberts-Thomson KF. Hospitalized head injuries among older people in Australia, 1998/1999 to 2004/2005. Inj Prev [Internet]. 2007 [cited 2013 Sept 6]; 2(13):243-7. Available from: http://www.ncbi.nlm.nih.gov/pmc/articles/PMC2598353/pdf/243.pdf

26. Pressley JC, Barlow B, Quitel L, Jafri A. Improving access to comprehensive injury risk assessment and risk factor reduction in older adult populations. Am J Public Health [Internet]. 2007 [cited 2013 Sept 6];97(4):676-8. Available from: http://www.ncbi.nlm.nih.gov/pmc/ articles/PMC1829339/pdf/0970676.pdf

27. Scheetz LJ, Zhang J, Kolassa JE. Using crash scene variables to predict the need for trauma center care in older persons. Res Nurs Health [Internet]. 2007 [cited 2013 Sept 6];30(4):399-412. Available from: http://onlinelibrary.wiley.com/doi/10.1002/nur.20203/pdf

28. Lee KK, Seow WT, Ng I. Demographical profiles of adult severe traumatic brain injury patients: implications for healthcare planning. Singapore Med J [Internet]. 2006 [cited 2013 Sept 6];47(1):31-6. Available from: http://www.sma.org.sg/smj/4701/4701a4.pdf

29. Yee WY, Cameron PA, Bailey MJ. Road traffic injuries in the elderly. Emerg Med J [Internet]. 2006 [cited 2013 Sept 6];23(1):42-6. Available from: http://www.ncbi.nlm.nih.gov/pmc/articles/PMC2564127/

30. Mathias TAF, Mello Jorge MHP, Andrade OG. Morbimortalidade por causas externas na população idosa residente em município da região sul do Brasil. Rev Latino Am Enfermagem [Internet]. 2006 [citado 2013 ago. 6];14(1):17-24. Disponível em: http://www.scielo.br/pdf/rlae/ v14n1/v14n1a03.pdf

31. Augenstein J, Digges K, Bahouth G, Dalmotas D, Perdeck E, Stratton J. Investigation of the performance of safety systems for protection of the elderly. Annu Proc Assoc Adv Automot Med [Internet]. 2005 [cited 2013 Sept 6];49:361-9. Available from: http://www.ncbi.nlm.nih. gov/pmc/articles/PMC3217455/

32. Kent R, Henary B, Matsuoka F. On the fatal crash experience of older drivers. Annu Proc Assoc Adv Automot Med [Internet]. 2005 [cited 2013 Sept 6];49:371-91. Available from: http://europepmc.org/backend/ptpmcrender.fcgi?accid=PMC3217450\&blobtype=pdf

33. Scheetz LJ. Relationship of age, injury severity, injury type, comorbid conditions, level of care, and survival among older motor vehicle trauma patients. Rev Nurs Health [Internet]. 2005 [cited 2013 Sept 6];28(3):198-209. Available from: http://onlinelibrary.wiley.com/ doi/10.1002/nur.20075/pdf.

34. Braver ER, Trempel RE. Are older drivers actually at higher risk of involvement in collisions resulting in deaths or non-fatal injuries among their passengers and other road users? Inj Prev [Internet]. 2004 [cited 2013 Sept 6];10(1):27-32. Available from: http://injuryprevention. bmj.com/content/10/1/27.full.pdf+html.

35. Gawryszewski VP, Mello Jorge MHP, Koizumi MS. Mortes e internações por causas externas entre os idosos no Brasil: o desafio de integrar a saúde coletiva e a atenção individual. Rev Assoc Med Bras [Internet]. 2004 [citado 2013 set. 6];50(1):97-103. Disponível em: http:// www.scielo.br/pdf/ramb/v50n1/a44v50n1.pdf

36. Liberman M, Mulder DS, Sampalis JS. Increasing volume of patients at level I trauma centres: is there a need for triage modification in elderly patients with injuries of low severity? Can J Surg [Internet]. 2003 [cited 2013 Sept 6];46(6):446-52. Available from: http://www. ncbi.nlm.nih.gov/pmc/articles/PMC3211761/.

37. Souza RKT, Soares DFPP, Mathias TAF, Andrade OG, Santana RG. Idosos vítimas de acidentes de trânsito: aspectos epidemiológicos e impacto na sua vida cotidiana. Acta Sci Health Sci [Internet]. 2003 [citado 2013 ago. 6];25(1):19-25. Disponível em: http://periodicos. uem.br/ojs/index.php/ActaSciHealthSci/article/view/2247/1467 